\title{
Educational Communication under the Influence of Digital Changes
}

Adriana Denisa Manea 


\title{
Educational Communication under the Influence of Digital Changes
}

\author{
Adriana Denisa Manea ${ }^{\text {a* }}$ \\ ${ }^{a}$ Babeș-Bolyai University, Faculty of Psychology and Educational Sciences, 7 Sindicatelor Street, Cluj-Napoca, 400029, Romania \\ *Corresponding author: adriana.manea@ubbcluj.ro
}

Abstract

Keywords: communication, education, technology, digitalisation

The reforming dynamism that the technological revolution supports has influenced the educational system. The reform of educational systems as innovative, coherent and flexible entities also meant digital transformations, educational technology systems aimed both at the educational space and the means/instruments of learning. Computerised systems have allowed for emphasised digital communication within the educational field, for mediated learning, self-control and self-adjustment. Consequently, education and self-education in the digital society have urgently called for the building of digital skills, technological abilities for all learners

\section{Zusammenfasung}

Schlüsselworte: Kommunikation, Bildung, Technologie, Digitalisierung
Die reformistische Dynamik der technologischen Revolution hat das Bildungssystem geprägt. Die Reform der Bildungssysteme als innovative, kohärente und flexible Ensembles setzte gleichzeitig digitale Transformationen voraus, Ensembles der Bildungstechnologie, die sowohl auf die Bildungsräume als auch auf die Mittel / Werkzeuge des Lernens abzielten. Computergestützte Systeme haben eine akzentuierte digitale Kommunikation im Bereich Bildung, vermitteltes Lernen, Selbstkontrolle und Selbstregulierung ermöglicht. Daher haben Bildung und Selbstbildung in der Computergesellschaft dringend die Bildung digitaler Fähigkeiten und technologischer Fähigkeiten auf der Ebene aller Lernenden erforderlich gemacht.

\section{Introduction.}

The information knowledge and society are components of the same educational set that cannot be separated: knowledge is meaningful information and acting information. For this reason, knowledge society will not be possible unless it engrafts on information society, as the two cannot be set apart. At the same time, knowledge society is more than information society through the major part that information plays- knowledge within society. The best meaning of knowledge society is probably that of information society- knowledge society (Iancu, 2009).

"Knowledge society grants new dimensions to the learning process. This is no longer exclusively located in educational facilities. By and large, learning is transferred, progressively, from schools towards companies and institutions, from learners and students towards workers. In nowadays society, one promotes educational systems that are projected according to the features of a dynamic and open society: market economy, democracy, administrative decentralisation, digitalisation, using ecology as an adjustment measure between man and nature etc. The aim of education is to cultivate individuals with abilities to adapt and integrate in the workplace and in community, to communicate efficiently in a variety of shapes and contexts, to access, analyse and manage data by using ICT and mass-media, to collaborate and partake in team work, to adapt to various roles and responsibilities, to stimulate creativity, intellectual curiosity, critical thinking and receptivity of novelty, to show respect for diversity and difference, social responsibility etc." (Albulescu, 2019, p.17).

\section{The typology of communication in the knowledge society}

Knowledge cannot be supported outside effective communication. Communication is an evolving process in close relation with the development of the human species, an essential process to maintain interpersonal relations, the exchange of information, ideas, feelings, connections that stand at the basis of social organisation. We differentiate, from the point of view of concepts, three types of communication with which we operate in the school and social environment at the same time, namely human/interpersonal communication, educational communication and didactic communication. 
Human communication represents a fundamental method of psychosocial interaction between individuals, which takes place in complex systems and languages (verbal, nonverbal, paraverbal language, gestures, symbolism of colours, rhythm or artistic expression, mathematical), where the exchange of information is enabled by generalized meanings and symbols in view of preserving stability or in order to generate attitudebehavioural changes.

Educational communication is the basis of all educational processes, at all levels, regardless their content and complexity, shapes or partners involved in the process. It encompasses a system of interpersonal processes in which educational agents are directly engaged in educational endeavours and within which there are reciprocal exchanges of messages, meanings, decisions, value judgments, emotional states and influences regarding the educational processes, with the help of components/elements of personal communication repositories, with the purpose of reaching educational finalities. It must be noted that in the educational context, communication may also be unpersonal when it is computer mediated, namely, it is performed via IT devices (digitalised technology). According to the aimed objective, the educational context allows the use of group educational communication (communication between the teacher and students), mass communication (communication between the teacher and parents at an extracurricular activity, meeting, conference communication, etc.)

Didactic communication a particular form of educational communication, is specific to didactic activities and endeavours, meant for systematic and assisted learning. It represents the exchange of information between teachers and students who are in a particular educating context. Didactic communication takes place as a "complex, multiphase transfer and through several information channels between two entities (individuals or groups) that simultaneously or successively take over the roles of transmitters and receivers, signifying desirable contents in the context of the instructiveeducative context" (Cucoş, 2002, p.178). Didactic communication is both instrumental (with the intention of causing an effect in the interlocutor) and consummatory (without such intention) because "the act of educational communication is not performed mechanically, but based on an interhuman climate that contains and mimics all the data referring to interpersonal relationships" (Ezechil, 2002, p.10).

Educational communication and the didactic communication may be considered specialised forms of the extremely complex and dynamic phenomenon of interpersonal communication.

In the current educational context, as a result of the technical-scientific revolution, the three types of communication above-mentioned may also add digital communication. The meaning of digital communication refers to the interaction that takes place in a virtual environment and requires the sharing of messages (which may be emoticons, emails, SMS, posts etc.) between the source (transmitter) and the receiver, by means of digital devices. Modern educational means create various opportunities to enable digital communication, and specialists estimate an increase in resource digitalisation as well as an expansion of customised apps. We may thus note, to exemplify, the existence of digital textbooks and their occurrence in the Romanian educational system, as well as e-books, electronic educational materials, PowerPoint presentations, educational platforms, forums, videoconferences, social networks etc.

\section{Educational realities in the digital age}

Being under the print of mechanisation, nowadays society is characterised by seed, increased information flow, rapid and significant changes. Hence, it is necessary to introduce mechanisms that facilitate change, respectively adaptation and re-adaptation. The high interest of university teachers for continuing education shows there is an awareness of the teacher's need to face the change, the complex and the new situations that might occur (Manea, 2014). The easy adjustment to the digital society of the future requires a development of digital skills within all teachers, which may be ensured through initial and ongoing training, building scientific skills that are necessary for the selection and efficient use of information (Manea \& Stan, 2016). Within the educational field, the progress of digital technologies has marked the accessibility of learning through the occurrence of virtual libraries, learning/training performed by a teacher/specialist who is thousand kilometres away, essential decrease in the costs for self-development and ongoing training (Manea, 2014). "Technology and technological elements are able to support the completion of transversal objectives that are so important in the 
process of developing a young person's personality and his/her becoming autonomous (intellectual curiosity, joy and pleasure to learn, the feeling of controlling things and mastering knowledge and skills, identifying valid sources of information, managing data according to specific issues and structuring the information)" (Manea, 2019, p. 32).

Educational facilities have constantly made use of audio-video educational resources in order to improve the understanding of information and to correctly operate with it. Therefore, the learning process in our digitalised society is carried out with and throughout technological resources, technological instruments that are specific to the didactic process of teaching-learning-evaluation. This way, we may find such elements both from the perspective of digitalised infrastructure (sending/ receiving information, storing information materials, registration of personal data, generating learning reports) as well as the actual learning environment (class/ virtual learning community).

The use of modern technologies in education gave birth to a revolution in the field of learning, one that seems to be in constant movement. Given that teachers and school institutions are under a permanent pressure to move away from the types of static education/learning, related to textbooks and physical location, students become avid data and information consumers, who require guidance and input customisation. In this respect, digital literacy functions as a bidirectional means of matching offer and demand available on the educational market of content and methodology (Mudure-Iacob, 2019). The use of NICT (New Information and Communication Technology) in learning and knowledge can be found under various shapes, from computer-assisted learning, e-learning, electronic lectures, distance-learning and training etc., to multimedia based learning. In audio-visual education or multimedia based learning, solving theoretical and practical issues of training mainly belong to the use of new information and communication technology, of equipment that allows class-and distance- display of image and sound, in view of improving understanding and maintaining of the taught information. The existence of a variety of educational levers is meant to enable users to make more efficient use of mass-media instruments, the Internet and computers throughout their entire lives, in order to gain access to information and to master the means of accessing valid, reliable and scientific data. (Uzunboylu \& Sarigoz, 2015). Consequently, digitalisation requires the building of digital skills and abilities that allow individuals to make use of the digital resources. The set of key-abilities (digital learning skills, digital data searching skills, digital responsibility, digital collaboration, productivity and digital creativity) includes those abilities to make proper and secure use of information technology, a vital learning and knowledge instrument for the workforce market, for one's leisure time and used in communication. (http://ec.europa.eu/social/BlobServlet? docId $=15688$ \&langId $=$ en) .

At the level of educational reality, the restructuring that took place is both under the print of tech revolution and the multiplication of educational dimensions (curriculum design -inter and transdisciplinary, adaptability, creative/ innovative learning), better retention of educational action (life-long learning, self-education) and emphasis on the prospective character of education (by linking nowadays education to the education of the future). School institutions must be in charge of instructing students regarding the development of a proactive attitude towards learning, the building of a constructivist approach centred on self-learning and self-education, especially since selfeducation means self-awareness, self-control and selfguidance (Manea, 2015, p. 171). Accordingly, there is a need for an increased mobilisation in order to design and implement new educational models, to accomplish effective didactic communication that is in close relation to the intellectual and skill potential of the students, time resource, socio-cultural mobilities and the scientifictechnological realm. This multidimensional and complex endeavour also calls for active and responsible engagement of the trainer and trainee from the point of view of cognition, metacognition and creativity. Moreover, the trainer-trainee couple needs to identify the intellectual, material and temporal resources in view of generating psychosocial behaviours that correspond to the requirements of the current and future society, by promoting personalities characterised by dynamism, flexibility and adaptability (Manea, 2018).

\section{Conclusions}

The acquisition of the communication skill expressed in all its forms (oral, written, digital) is a consequence of learning, of experimenting and exercise practiced in the presence or absence, of the capacity to communicate as native gift. Therefore, the interhuman communication exercise, be it educational or didactic, generates the communicativeness that is expressed through availability 
towards the other, through generation of direct interaction and sociability. When engaging in a form of efficient educational communication, communication that is constantly under the pressure of transforming factors of the digital age, it is necessary to maintain communication interactivity through satisfaction of knowledge needs empathy practice and assertiveness. Therefore, communication skills, which are so necessary in a knowledge society, may be acquired only by means of joint effort from the state institutions and communication actors at the same time.

\section{Authors note:}

Adriana Denisa Manea, Ph.D., is senior lecturer at the Educational Sciences Department in the Faculty of Psychology and Educational Sciences, Babes-Bolyai University, Cluj-Napoca). In 2010 she received her $\mathrm{PhD}$ in Educational Sciences with the thesis: School as organisation. The democratic-participative management and its implications at the level of the Inclusive Education School Centre Beclean. Her didactic and research fields are communication pedagogy, adult pedagogy, inclusive education, class and school unit management, psychosociology of the family.

\section{References:}

Albulescu, I. (2019). Educaţia timpurie în România şi în context European. In Albulescu, I., \& Catalano H., Sinteze de pedagogia învăţământului preşcolar, Bucureşti: Editura Didactica Publishhing House.

Cucoş, C. (2014). Pedagogie. Ediția a III-a revăzută și adăugită Iaşi: Polirom Publishing House.

Ezechil, L. (2002). Comunicarea educaţională în context şcolar. Bucureşti: Editura Didactică și Pedagogică Publishing House.

Iancu, Ş. (2009). Societatea cunoaşterii necesită gândire. In Cogito Open Access Journal, Vol. 1, no.2, pp. 82 - 91.

Manea, A.D. (2014). Lifelong learning programs - an effective means of supporting continuing education. In Procedia Social and Behavioral Sciences, 142 pp. $454-458$.

Manea, A.D. \& Stan, C. (2016). Online communication. In The European Proceedings of Social \& Behavioural Sciences. Vol. VIII, 12/40 pp. 317-323.

Manea, A.D. \& Stan, C. (2017). Study regarding the use of information and communications technology. In The European Proceedings of Social \& Behavioural Sciences. no.33, pp. 271-277.

Manea, A.D. (2019). Educational values within the scope of the technological revolution. In Astra Salvensis, Vol. VII no. 14, pp. $32-26$.

Manea, A.D. (2015). Coordinates of Lifelong Education. In Astra Salvensis, Vol. V, p. 171-177.
Manea, A.D. (2018). Features of Educational Activities in the Contemporary Society. In Astra Salvensis, Vol. VI, no. 12, pp. 255-260.

Mudure-Iacob, I. (2019). Digital literacy: from multi-functional skills to overcoming challenges in teaching ESP. In Astra Salvensis, Vol. VII, no. 14, pp. 56-62.

Uzunboylu, H. \& Sarigoz, O. (2015). The Evaluation of Anthropological Attitudes, available online at: https://www.theatlas.com/charts/E1Wxox0c, accessed 13. 06. 2016.

http://ec.europa.eu/social/BlobServlet?docId=15688\&langId=en (accessed 25. 08. 2017). 